\title{
Occurrence of Cinara spp. (Hemiptera, Aphididae) on Pinus spp. (Pinaceae), in the county of Lages-SC, Brazil ${ }^{1}$
}

\author{
Fernanda N. Lázzari² ${ }^{2}$ Rosita F. R. Trentini³ \& Regina C. Z. de Carvalho ${ }^{4}$
}

\author{
${ }^{1}$ Contribution $n^{0} 1441$ of the Departamento de Zoologia, Universidade Federal do Paraná. \\ ${ }^{2}$ Departamento de Zoologia, Universidade Federal do Paraná. Caixa Postal 19020, 81531-980 Curitiba-PR, Brazil. E-mail: \\ ferlazzari@brturbo.com \\ ${ }^{3}$ In memorian \\ ${ }^{4}$ Centro de Diagnóstico Marcos Enrietti - SEAB. Rua Jaime Balão 575, 80040-340 Curitiba-PR, Brazil.
}

\begin{abstract}
A population survey of the giant conifer aphid Cinara spp. was carried out in two areas of Pinus elliottii using yellow pan traps, during two years, from July 1997 to June 1999. During the collection period, the predominant species was Cinara pinivora (Wilson, 1919), representing 99\% of the collected species. A few specimens of Cinara maritimae (Dufour, 1833) and only one winged female of Cinara fresai Blanchard, 1939 were collected. The population of $C$. pinivora was statistically higher in the area with 4.5 year-old trees than in the 1.5 year-old ones. The highest population peaks were registered in July 1997 and in August 1998. An unexpected high number of winged parthenogenetic females was collected in December 1998. C. fresai Blanchard, 1939 is recorded for the first time for Brazil.
\end{abstract}

KEYwords. Faunistics; giant conifer aphids; insect survey; yellow pan traps.

Resumo. Ocorrência de Cinara spp. (Hemiptera, Aphididae) em Pinus spp. (Pinaceae), em Lages-SC, Brasil O levantamento populacional do pulgão-gigante-do-pinus, Cinara spp. foi desenvolvido em duas áreas de plantio de Pinus elliottii utilizando armadilhas-amarelas-de-água, durante dois anos, de julho de 1997 a junho de 1999. Durante o período de coletas, a espécie predominante foi Cinara pinivora (Wilson, 1919), representando 99\% de todas as espécies coletadas. Alguns espécimes de Cinara maritimae (Dufour, 1833) e apenas uma fêmea alada de Cinara fresai Blanchard, 1939 foram coletados, sendo este o primeiro registro de C. fresai no Brasil. A população de C. pinivora foi estatisticamente superior na área com árvores de 4,5 anos em relação à de 2,5 anos de idade. Os picos populacionais foram registrados em julho de 1997 e em agosto de 1998. Um inesperado número de fêmeas partenogenéticas aladas foi coletado em dezembro de 1998.

Palavras-Chave. Armadilha-amarela-de-água; faunística; levantamento de insetos; pulgão-gigante-do-pinus.

In the last decades there has been, in Brazil, a fast increment in the areas reforested with species of Pinus, introduced mainly from the United States of America and Australia. It was due to a Brazilian program to support both forestation and reforestation, effective from 1966 to 1987, in order to reduce pressure on native forests and to supply the material needed for paper, cellulose and wood industries (SHIMIZU 1986). From the approximately five million hectares of reforestation, in Brazil, about two million hectares are composed mainly of Pinus elliottii L. and P. taeda Englem, in the Southern and Southeastern regions of the country (OliveIRA \& AHrEns 1987; PenTEAdo 1995).

The environmental unbalance, resultant of extensive monoculture areas and other inadequate forestry practices, has been turning the plantations more and more susceptible to the attack of pests and diseases. In 1996, aphids of the species Cinara pinivora (Wilson, 1919) (Lachninae, Cinarini) were detected causing severe damages on Pinus trees, in the counties of Cambará do Sul (RS) and Lages (SC), in Southern Brazil, particularly during the winter (PENTEADO et al. 2000). In 1998, another species, Cinara atlantica (Wilson, 1919) was detected presenting larger geographical and seasonal distribution than that of $C$. pinivora.

Only three species of Cinara had been registered until 1993 in Brazil: Cinara (Cinarella) maritimae (Dufour, 1833) on Pinus elliottii, $P$. densiflora, $P$. thumbergii, and on $P$. caribae bahamensis; Cinara (Cinarella) piniformosana (Takahashi, 1923), on P. densiflora, P. thumbergii and Pinus spp.; Cinara (Cupressobium) tujafilina (del Guercio, 1909), on Cupressus (Costa et al. 1993). According to these authors, a fourth species, Cinara (Cupressobium) fresai Blanchard, 1939, widespread in Argentina, Chile and Colombia, is probably present in Brazil, but it was not collected so far.

The genus Cinara is composed of about 200 species that occur on conifers distributed around the world (BLACKMAN \& EASTOP 1984). The attacked trees have their development retarded, needle shedding, branch twisting and abundant production of honeydew that favors sooty mold development, affecting photosynthesis (PENTEADO et al. 2000). Forest pests such as the giant conifer aphids are difficult to be controlled by conventional insecticide applications.

According to PATTI \& Fox (1981), the damages are more 

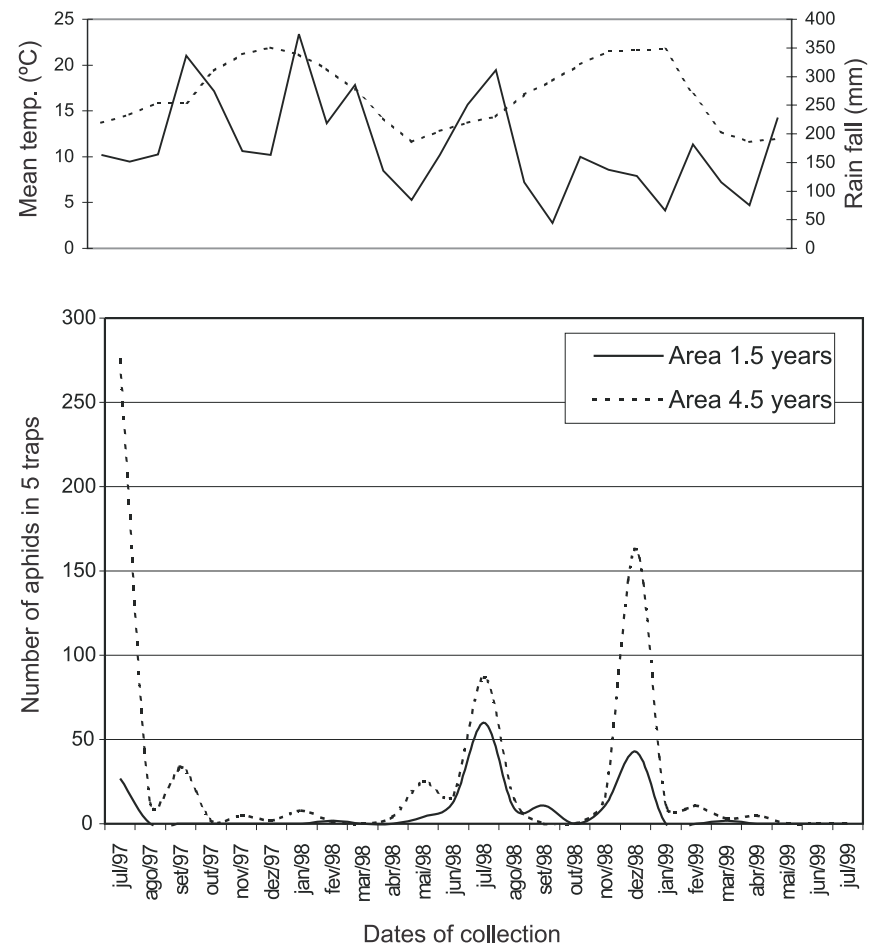

Fig. 1. Number of collected specimens of Cinara spp. and climatic data (mean temperature_and precipitation - - -) in two areas of Pinus elliottii, in Lages-SC, July 1997 to July 1999.

intense on young trees. Fox \& GRIFFITH (1977), working with two year-old $P$. taeda infested by $C$. atlantica in South Carolina, observed significant reduction in diameter and height of infested trees by the end of the third year. ZALESKI (2003) also observed high reduction in growth of pine seedlings exposed to different infestation levels of C. atlantica in a greenhouse.

The objective of this research was to determine the influence of temperature and rainfall on the occurrence of Cinara species, and to evaluate their presence on areas of Pinus with different ages, in order to provide information for biological control programs.

\section{MATERIAL AND METHODS}

The collection was accomplished every fifteen days, for a two-year period, from July 1997 to June 1999, in two areas of $P$. elliottii, one with 1.5 year-old trees and the other with 4.5 year-old trees, at the beginning of the collections, in the county of Lages, in the state of Santa Catarina, Brazil. Each area had approximately 80 ha of Pinus, with space of $2 \times 2.5 \mathrm{~m}$, with 2000 trees/ha; the trees were pruned and the areas cleaned periodically. Five yellow pan traps (Möericke type) were distributed in 1 ha of each area, one at the center and one at each corner, placed on $1.30 \mathrm{~m}$ height wood supports. The aphids were removed from the traps with a fine brush and placed in vials with $70 \%$ ethanol, then taken to the laboratory for screening and identification of the material. Temperature and precipitation data were registered by the Estação Agrometeorológica de Lages, nearby the experimental areas.

\section{RESULTS ANDDISCUSSION}

During the two years of collections, the predominant species in both areas was C. pinivora, with 1216 specimens, representing $99 \%$ of the Cinara specimens collected with the traps. The other species of Cinara were 11 nymphs and two winged females of $C$. maritimae and a winged female of $C$. fresai, which was registered in May of 1999. CosTA et al. (1993) mentioned that $C$. fresai was probably present in Brazil because it occurs in Argentina, Chile and Colombia, but it had not been collected until now. Thus, this is the first record of $C$. fresai in Brazil.

The number of $C$. pinivora collected was statistically higher (1035 specimens) in the 4.5 year-old trees area than the number (181) collected by the traps in the 1.5 year-old trees area. The highest population peak was in July 1997 (Fig. 1), then the population decreased to insignificant numbers for the next months, and increased again only on August 1998. On December 1998, a high number of parthenogenetic winged females were collected. This was quite unusual because this species was restricted to the winter months and in cooler geographical areas (PenteAdo et al. 2000). It has been demonstrated that outbreaks are usually recorded when an exotic pest is introduced into a new area because natural enemies may not be present to control such pest (WALLNER 1996).

Despite the much lower number of aphids in the 1.5 year old trees when compared to the 4.5 year old trees, the populational patterns were very similar.

It can be noticed that there is an inverse correlation between C. pinivora collections by the traps and temperature; they are usually higher during the winter, despite the unusual peak registered once during the summer. It was observed (Wilson Reis Filho, personal communication) that Cinara specimens go down to the roots and to ant nests during the summer months.

Recent Cinara surveys on Pinus trees by using yellow pan traps have shown that $C$. pinivora is occurring in very low numbers and is being replaced by $C$. atlantica, which populations are higher and more widespread than the former species (Edson T. Iede, personal communication). These findings are very useful to follow the patterns of these pine aphids and to add information for biological control programs.

Acknowledgements. To EMBRAPA Floresta for the technical support to carry out this research.

\section{REFERENCES}

Blackman, R. L. \& V. F. Eastop. 1994. Aphids on the World's Trees - An Identification and Information Guide. Wallingford, CAB International, $151+987 \mathrm{p}$. 
Costa, C. L.; V. F. Eastop \& R. L. Blackman. 1993. Brazilian Aphidoidea: II. Accounts of the Lachninae, Chaitophorinae, Greenideinae, Anoeciinae, and Hormaphidinae. Pesquisa agropecuária brasileira 28(3): 269-280.

Fox, R. C. \& K. H. Griffith. 1977. Pine seedling growth loss caused by cinaran aphids in South Carolina. Journal of Georgia Entomological Society 12: 29-34.

Oliveira, Y. M. M. \& S. Ahrens. 1987. Curvas de índice para povoamentos de Pinus elliottii var. elliottii Englem. e P. taeda L. estabelecidos no sul e sudeste do Brasil: resultados preliminares. Circular técnica 14, setembro/1987, EMBRAPA, 11 p.

Patti, J. H. \& R. C. Fox. 1981. Seasonal occurrence of Cinara spp. and Essigella pini Wilson on loblolly pine, Pinus taeda L. Journal of Georgia Entomological Society 16: 96-105 p.

Penteado, S. R. C. 1995. Métodos de amostragem para avaliação de Sirex notilio F., 1793 (Hymenoptera: Siricidae) e de seus inimigos naturais, em Pinus taeda L. e aspectos do controle biológico. Tese de Mestrado. Curitiba, Universidade Federal do Paraná, $92 \mathrm{p}$.

Penteado S. R. C.; R. F. Trentini; E. T. Iede \& W. Reis Filho. 2000. Pulgão do Pinus: nova praga florestal. Série Técnica Instituto de Pesquisas e Estudos Florestais 13(33): 97-102.

Shimizu, J. Y. 1986. Interação genótipo e ambiente em Pinus elliottii no sul do Brasil. Boletim de Pesquisa Florestal, junho/1986, 12 12-20.

Wallner, W. E. 1996. Invasion of the tree Snatchers. The Asian gypsy moth's entrance into North America shows that exoticpest invasions can happen in unexpected ways. Reprinted from American Nurseryman. Chicago, 3 p.

Zaleski, S. R. M. 2003. Biologia, danos e determinação dos limites térmicos para o desenvolvimento de Cinara atlantica (Wilson, 1919) (Hemiptera: Aphididae) em Pinus taeda L. (Pinaceae). Tese de Mestrado. Curitiba, Universidade Federal do Paraná, 70 p. 